\title{
Zingiber Officinale Roscoe and Echinops Kebericho Mesfin Showed Antiplasmodial Activities against Plasmodium Berghei in a Dose- dependent Manner in Ethiopia
}

\author{
Abdissa Biruksew ${ }^{*}$, Ahmed Zeynudin ${ }^{1}$, Yonas Alemu ${ }^{1}$, Lemu Golassa ${ }^{5}$, Moti \\ Yohannes $^{2}$, Asfaw Debella ${ }^{3}$, Geme Urge ${ }^{6}$, Bart De Spiegeleer ${ }^{7}$, Sultan Suleman ${ }^{4}$
}

\footnotetext{
OPEN ACCESS

Citation: Abdissa Biruksew, Ahmed Zeynudin, Yonas Alemu, et al. Zingiber Officinale Roscoe and Echinops Kebericho Mesfin Showed Antiplasmodial Activities against Plasmodium Berghei in a Dose-dependent Manner in Ethiopia.

Ethiop J Health Sci.2018;28(5):655. doi:http://dx.doi.org/10.4314/ejhs.v28i5.17

Received: January 22, 2018

Accepted: January 24, 2018

Published: September 1, 2018

Copyright: (C) 2018 Abdissa Biruksew, et al. This is an open access article distributed under the terms of the Creative Commons Attribution License, which permits unrestricted use, distribution, and reproduction in any medium, provided the original author and source are credited.

Funding: the study was finanaced by Jimma University.

Competing Interests: The authors declare that this manuscript was approved by all authors in its form and that no competing interest exists.

Affiliation and Correspondence:

${ }^{1}$ School of Medical Laboratory

Sciences, Faculty of Health Sciences,

Jimma Institute of Health, Jimma

University, Ethiopia

${ }^{2}$ School of Veterinary Medicine, Jimma

University, Ethiopia

${ }^{3}$ Department of Traditional and Modern Drug Research, Ethiopia ${ }^{4}$ School of Pharmacy, Faculty of Health Sciences, Jimma Institute of Health, Jimma University, Jimma, Ethiopia

${ }^{5}$ Aklilu Lemma Institute of

Pathobiology, Addis Ababa University

${ }^{6} 305$ Pennshire Dr Lancaster, USA

${ }^{7}$ Drug Quality and Registration (DruQuaR) group, Faculty of Pharmaceutical Sciences, Ghent University, Belgium

*Email: abdissa.hordofa@ju.edu.et
}

\section{ABSTRACT}

BACKGROUND: The emergence and spread of Plasmodium falciparum resistance to antimalarial drugs necessitated the search for new drugs from natural products. Zingiber officinal Roscoe and Echinops Kebericho Mesfin are traditional herbal medicines widely used for the treatment of malaria in Ethiopia. The aim of the study was to assess the toxicity profile and in vivo antiplasmodial activities of $70 \%$ methanol crude extracts of both plant materials against Plasmodium berghei.

METHODS: Healthy male Swiss Albino mice of age 4-5 weeks and weight 25-36 $g$ were infected by $P$. berghei. The extracts were administered orally at doses 5000,2500 and $1250 \mathrm{mg} / \mathrm{kg}$ for acute toxicity of E. kebericho Mesfin. Graded doses at 1000, 500 and 250 mg/kg used for four days suppressive studies. Parasitemia, body weight, packed cell volume (PCV) and survival time were determined. SPSS Version 20 was used for the analysis of data of parasitemia, body weight, PCV, and survival times. Statistical significance was determined by one-way ANOVA. Independent ttest was used to compare results. Results were presented as a mean \pm standard error of the mean $(M \pm S E M)$. All data were analyzed at a 95\% confidence interval $(\alpha=0.05)$.

RESULTS: At the dose of $5000 \mathrm{mg} / \mathrm{kg}$, E. kebericho Mesfin showed no toxic effects. The LD50 of extract could go beyond the dose used. In vivo antiplasmodial activity of extracts showed excellent chemo suppression at 500 and $1000 \mathrm{mg} / \mathrm{kg}$ in a dose dependent manner compared with the negative control. The chemo suppressions of the $1000 \mathrm{mg} / \mathrm{kg}$ of both plant extracts were $49.53 \pm$ $1.90 \%$ and $32.83 \pm 1.03 \%$, respectively. The survival times of $P$. berghei infected mice were also a dose dependent manner while failed to prevent weight loss.

CONCLUSION: The extracts of both medicinal plants showed antiplasmodial activities against $P$. berghei. It confirmed the literature findings and their traditional uses.

KEYWORDS: Echnops kebericho Mesfin, Zengibir officinale Roscoe, Plasmodium berghei, oral acute toxicity, antiplasmodial 


\section{INTRODUCTION}

Malaria is a global public health threat infecting an estimated 212 million and causing 429, 000 deaths in 2015. However, the current prevention and control measures have led to a $29 \%$ reduction in malaria mortality rates globally. Sub-Saharan Africa still carries a huge share of malaria burden. Thus, the continent has been home to $90 \%$ of malaria morbidity and $92 \%$ of mortality rates (1) . In response to the emergence and spread of Plasmodium falciparum resistance to chloroquine (CQ) and sulfadoxine- pyrimethamine (SP), the World Health Organization (WHO) has recommended the use of artemisinin-based combination therapy (ACT). ACTs have been used in reducing malaria burden and play an important role in maintaining the current success of control programs (2). Nowadays, the increase in global travel and population movement augments resistant parasite spread to any part of the world (3-5) leading to treatment failures and decreased efficacies. Emergence and spread of P. falciparum resistance to ACTs in South-eastern Asia threaten global malaria efforts. The declining efficacy of the classical antimalarial medicines, resistance of vectors to insecticides and failure of developing effective vaccines have led to an urgent need for searching new and efficient antiplasmodial candidates from natural products $(6,7)$.

Studies uncovered that modern pharmacopeia still contains at least $25 \%$ drugs derived from plants and many others which are synthetic analogs built on prototype compounds isolated from plants $(8,9)$. About $90 \%$ of the Ethiopian population rely on traditional medicines including herbal products for their primary health care needs (10). Moreover, medicinal plants have played a profound role for the treatment of human malaria due to the presence of antiplasmodial compounds in several plant species (11). Quinine, for instance, was extracted from Cinchona bark, while CQ and primaquine were synthesized as new antiplasmodial agents, artemisinin, a potent partner drug in ACTs, was discovered from the Chinese medicinal plant by the
Noble prize winner Chinese Professor, Tu Youyou (12).

Artemisia annua, the only available effective antimalarial drug against resistant strains of Plasmodium parasites (13). It attracted the attention of many researchers and stakeholders to look for new antiplasmodial remedies from natural products.

In Ethiopia, there are a number of medicinal plants traditionally used for the treatment of malaria and/or fever. Among which Zingiber officinale Roscoe and the indigenous plant, Echinops kebericho Mesfin are the two most common ones $(14,15)$.

Echinops is one of the genera classified under the family Asteraceae. E. kebericho Mesfin (Qabarichoo in Afaan Oromoo) is endemic to Ethiopia confined only to the highlands (14). Kebericho is so far known from a few localities in Ethiopia (Shawa and Gojam Provinces) at altitudes of $2300-2600 \mathrm{~m}$. It is an erect perennial herb or shrub up to $1.2 \mathrm{~m}$ high, commonly from a massive root stock with leafy stems (16). It has long been traditionally used specifically by the local practitioners (healers) against a wide range of ailments. These include malaria, migraine, mental illness, heart pain, lung Tuberculosis, leprosy, kidney disease, bilharzia, syphilis and amoebic dysentery (14).

$Z$. officinale Roscoe is commonly called Ginger, African ginger or Black ginger. It belongs to Zingiberaceae family. Ginger is a 2-4 foot tall perennial with grass like leaves up to a foot in length. Z. officinale Roscoe is mostly distributed in Asia, Africa, India, Jamaica, Mexico, and Hawaii (17) and it has been widely used in West African countries as an antimalarial agent (18-20). In general, the two medicinal plants have wider medicinal applications; therefore, this study was designed to investigate the traditional claims of antimalarial efficacy and safety of their use within the community using in vivo antiplasmodial activity and acute toxicity profiles.

\section{METHODS}

Extraction of the plant material was conducted at Jimma University Laboratory of Drug Quality

DOI: http://dx.doi.org/10.4314/ejhs.v28i5.17 
(JuLaDQ). The acute toxicity and antiplasmodial activity studies were conducted at Jimma University College of Agriculture and Veterinary Medicine, Experimental Research Laboratory from January to May n 2012.

Collection and preparation of plant material: Fresh rhizomes of Echinops kebericho Mesfin and roots of $Z$. officinale Roscoe were collected from Gindabarat, Gonfi Kedida which is located at an attitude of 9 33' 00" and longitude 37 53' 00" (21), West Oromia $200 \mathrm{~km}$ from Addis Ababa, Ethiopia. The plant materials were wrapped with plastic sheets during transportation. Collection of the plants was guided by the traditional healers, and species identification of the plants was made by a botanist at Jimma University herbarium. Plant specimens were deposited with voucher numbers 2348 and 2347 for E. kebericho Mesfin and Z. officinale Roscoe, respectively, at Jimma University Herbarium.

Extraction of plant materials: The plant materials were air dried at room temperature under shade and grounded to a powder using mortar and pestle. A total of $100 \mathrm{~g}$ of each plant material was extracted using Soxhlet apparatus with $400 \mathrm{ml}$ of $70 \%$ methanol. The mixtures were filtered using Whatman filter paper No.2 (Whatman ${ }^{\circledR}$, England). Methanol was evaporated from the extracts by a rotary evaporator (Buchi Rota vapor, Switzerland) under low pressure, and the final filtrate was stored in a tightly closed bottle container at $4^{\circ} \mathrm{C}$ until used (22). Each fresh experimental solute was prepared by $3 \%$ Tween 80 (Sigma - Aldrich).

The parasites: Chloroquine sensitive $\mathrm{P}$. berghei strain ANKA was obtained from Ethiopian Public Health Institute (EPHI) and maintained at the Animal House of Jimma University College of Agriculture and Veterinary Medicine (JUCAVM). The viability of parasites was maintained by serial passage at a standard inoculum of $1 \times 10^{7}$ of parasitized erythrocytes from donor mice to healthy ones in the experimental laboratory as described elsewhere $(23,24)$.

The experimental animal: Male Swiss albino NMRI mice 4-5 weeks of age and 25-36 g were procured from the breeding colony of School of JUCAVM, and donor mice were obtained from EPHI. They were then maintained on commercial pellet and water ad libitum and kept in $12 \mathrm{~h}$ dark and $12 \mathrm{~h}$ light in clean and fly-proof house stable one week prior to the commencement of experiment for acclimatization purpose. The health of the mice was followed by a veterinarian. The care of experimental animals was followed according to the standard set by the international guideline for animal care and use. The animals were then randomly assigned to different treatment groups of five, each in a cage.

Oral acute toxicity test: Twenty albino mice aged 4-5 weeks and weighing 25-36 g were randomly grouped into four groups of 5 mice; three treatment groups and one control group. The mice in the control group received 3\% tween 80 (vehicle), whereas the crude extracts of $E$. Kebericho Mesfin were orally administered in a vehicle using oral gavages at doses 5000, 2500 and $1250 \mathrm{mg} / \mathrm{kg}$ body weight.

Then, the mice were observed continuously for $4 \mathrm{~h}$ after administering the crude extract and followed for $24 \mathrm{~h}$ for any manifestations of toxicity. The median lethal dose (LD50) of the crude extracts was determined according to the method described earlier (25). Oral acute toxicity parameters such as body weight (measured on day 1, day 7 and day 14 ), hematological assay (26) and histopathological indices were determined on day 14 (27). It was reported that the toxicity of ginger had already been conducted and considered negligible with oral LD50 values in various animals exceeding $5 \mathrm{~g} / \mathrm{Kg}(28)$. Besides this fact, the plant has been recognized by U.S. Food and Drug Administration generally recognized as safe food supplement (29). Because of this report, we did not conduct the toxicity profiles of $Z$. officinale Roscoe.

In vivo antiplasmodial activity studies: Antiplasmodial activity of each of the test extracts was performed in a 4-day suppressive standard test as described earlier (30). Forty male Swiss Albino mice 4-5 weeks and weight 25-36 g were used to evaluate the antiplasmodial activity of both plant extracts. Donor mice infected with

DOI: http://dx.doi.org/10.4314/ejhs.v28i5.17 
rodent malaria parasite, $P$. berghei (with a raised parasitemia of 20-30\%) were sacrificed, and blood was collected via cardiac puncture with a sterile and disposable needle and syringe. The blood was diluted with normal saline in such a way that 0.2 $\mathrm{ml}$ of blood contained approximately $1-10^{7}$ infected red blood cells (31). Each mouse was inoculated intraperitoneally with $0.2 \mathrm{ml}$ of infected blood on the first day (D 0). The mice were then divided randomly into eight groups of five mice in each group. Three groups of mice were assigned to different treatment groups, and the other two groups were used as common controls (positive and negative). Three hours post infection, the treatment groups were orally administered with 1000, 500 and $250 \mathrm{mg} / \mathrm{kg} /$ day doses of each plant extract. Chloroquine tablet, (Batch Number 0123C3RJA, Addis Pharmaceuticals Factory PLC Adgrat, Ethiopia) at the dose of $25 \mathrm{mg} / \mathrm{kg} /$ day and vehicle (3\% Tween 80) were administered orally to the positive and negative control groups, respectively, for four consecutive days (D 0 to D 3).

On the fifth day (D 4), drops of blood were taken from the tail of each mouse and thick, and thin smears were made on the microscopic slide. The smears were then fixed with methanol and stained with $10 \%$ Giemsa. Four fields were examined on each slide. The number of infected and uninfected red blood cells were counted and the mean was taken according to previous works (31):

$$
\text { Parasitaemia }=\frac{\text { Total iRBCs }}{\text { Total RBCs counted }} \times 100 \%
$$

The percentage parasitemia and chemo suppressions were calculated according to the standardized test methods $(24,32)$. Therefore, the difference between the mean parasitemia value of the control group (taken as 100\%), and those of the experimental groups was calculated and expressed as percent reduction (activity) using either of the following Equations 1 and 2 (31):

$$
\text { Activity }=100-\left\{\frac{\text { mean parasitaemia in treated }}{\text { mean parasitaemia in control }}\right.
$$

Or

\section{Parasitaemia in negative control - Parataemia in study group Tochemosupression $=$ \\ Parasitaemia in Negative control}

Thus, a plant extract is considered to have antiplasmodial activity if it shows a reduction in parasitemia $\geq 30 \%$ (33).

Determination of packed cell volume and body weight of the mice: The PCV was measured to predict the effectiveness of the test extracts (34) on D 4. Blood from the tail of each animal was drawn in duplicate, and measurements were done as follows:

$$
\text { Packed Cell Volume }=\frac{\text { Volume of erythrocytes in a gived volume of blood }}{\text { Total blood Volume }}
$$

On D 0 and D 4, the body weight of each mouse was determined to observe whether the test extracts prevented the weight loss. The body weights of mice are commonly reduced with increasing parasitemia in infected mice (26).

Monitoring mean survival time: Mortality was monitored daily, and the number of days from the time of inoculation of the parasite up to death was recorded for each mouse in the treatment and control groups throughout the follow-up period. The mean survival time (MST) for each group was calculated using Equation 4 (35):

$M S T=\frac{\text { Sum of survival times of all mice in a group }(\text { days }}{\text { Total numbers of mice in that group }}$

Data analysis: Results were presented as a mean \pm standard error of the mean $(M \pm$ SEM). SPSS Version 20 was used for the analysis of data of parasitemia, body weight, PCV, and survival times. Statistical significance was determined by one-way ANOVA. Independent t-test was used to compare results. All data were analyzed at a $95 \%$ confidence interval $(\alpha=0.05)(26)$.

\section{RESULTS}

Oral acute toxicity assessment of Echinops Kebericho Mesfin: Oral acute toxicity studies revealed that the graded doses of $70 \%$ methanol extract of E. Kebericho Mesfin (maximum 5,000

DOI: http://dx.doi.org/10.4314/ejhs.v28i5.17 
$\mathrm{mg} / \mathrm{kg}$ ) did not show any signs of toxicity in mice. The experimental maximum dose did not show any lethal effects; revealing that the LD50 could be beyond the dose used. In this in vivo acute toxicity study, there was no gross physical and behavioral changes such as rigidity, sleep, diarrhea, depression, abnormal secretion and hair erection. Moreover, there were no significant differences between the control groups and the experimental arms with regard to body weight, hematological and histopathological parameters (Tables 1 and 2) at the aforementioned doses.

Table 1: Effects of 70\% methanol rhizome extract of Echinops kebericho Mesfin on body weight of mice in oral acute toxicity studies

\begin{tabular}{lllll}
\hline $\begin{array}{l}\text { Treatment group } \\
\text { (does in } \mathbf{~ m g / k g ) ~}\end{array}$ & \multicolumn{4}{l}{ Body weight(g) on three different days } \\
\cline { 2 - 5 } & Day 0 & Day 7 & Day 14 & p-value \\
\hline $5000 \mathrm{mg} / \mathrm{kg}$ & $33.00 \pm 1.650$ & $32.67 \pm 1.43$ & $35.0 \pm 1.26$ & 0.490 \\
$2500 \mathrm{mg} / \mathrm{kg}$ & $32.00 \pm 1.00$ & $35.33 \pm 1.28$ & $38.33 \pm 0.61$ & 0.002 \\
$1250 \mathrm{mg} / \mathrm{kg}$ & $28.50 \pm 0.99$ & $32.83 \pm 0.98$ & $37.0 \pm 0.816$ & 0.000 \\
Control & $26.17 \pm 2.50$ & $33.00 \pm 2.113$ & $36.67 \pm 1.23$ & 0.007 \\
\hline
\end{tabular}

Key: Values are expressed as $\operatorname{MEAN} \pm \mathrm{SEM}, \mathrm{n}=6$, day $0=$ initial day pretreatment weight:

7: D 14= weight on day 14

D $7=$ weight on day

Table 2: The effect of $70 \%$ methanol extracts of the rhizome of Echinops kebericho Mesfin on Haematological parameters in oral acute toxicity studies

\begin{tabular}{|c|c|c|c|c|}
\hline \multirow{2}{*}{$\begin{array}{l}\text { Treatment group } \\
\text { (does in } \mathrm{mg} / \mathrm{kg} \text { ) }\end{array}$} & \multicolumn{4}{|c|}{ Haematological parameters } \\
\hline & $\mathrm{WBC}\left(\times 10^{3} / / \mathrm{mm}^{3}\right)$ & $\operatorname{RBC}\left(\left(\times 10^{6} / \mathrm{mm}^{3}\right)\right.$ & Hgb (mg/dl) & НCT \% \\
\hline 5000 & $3.53 \pm 0.79$ & $7.93 \pm 1.64$ & $10.78 \pm 2.22$ & $40.18 \pm 8.31$ \\
\hline 2500 & $3.17 \pm 0.52$ & $9.78 \pm 0.53$ & $13.32 \pm 0.63$ & $50.21 \pm 2.72$ \\
\hline 1250 & $4.14 \pm 0.59$ & $10.25 \pm 0.62$ & $13.97 \pm 0.71$ & $47.82 \pm 1.03$ \\
\hline Control & $3.17 \pm 0.15$ & $8.78 \pm 0.35$ & $12.88 \pm 0.45$ & $49.70 \pm 0.96$ \\
\hline
\end{tabular}

Key: Values are expressed as Mean \pm SEM: $n=6$ : $T W B C=$ Total White Blood Cells: $R B C=$ Red Blood Cells: $\mathrm{Hgb}=$ Haemoglobin: $\mathrm{HCT}=$ Haematocrit

In vivo antiplasmodial Studies: In a four day suppressive tests, the in vivo antiplasmodial studies of the methanol extracts of both plants showed significant chemo-suppressions in a dosedependent manner as compared to the negative control (Table 4). Accordingly, the highest parasitemia suppressive effects of the rhizome extract of E. Kebericho Mesfin were $49.53 \pm 1.90$, $34.66 \pm 0.76$, and $22.13 \pm 0.87$ for 1000,500 , and $250 \mathrm{mg} / \mathrm{kg} /$ body weight; respectively (Table 4). The antiplasmodial activities of $Z$. officinale
Roscoe were also $32.83 \pm 1.03,23.49 \pm 1.47$, $19.87 \pm 0.84$ for 1000,500 , and $250 \mathrm{mg} / \mathrm{kg} /$ body weight; respectively. It can easily be inferred that the first and the second highest doses of both plant extracts showed profound chemo-suppression ( $\mathrm{P}$ $<0.001)$ in $P$. berghei infected animals. On the other hand, $1000 \mathrm{mg} / \mathrm{kg}$ of E. Kebericho Mesfin rhizome extract was found to be promising antiplasmodial activity than other graded doses. 
Table 4: Effects of 70\% methanol rhizome extracts of Echinops kebericho Mesfin and Z. officinale Roscoe on \% parasitemia, chemo-suppression and survival times of $P$. berghei infected mice

\begin{tabular}{lllll}
\hline Extracts & Doses (mg/kg) & \% Parasitemia & $\begin{array}{l}\text { \% Inhibition } \\
\text { (activity) }\end{array}$ & $\begin{array}{l}\text { Survival time } \\
\text { (days) }\end{array}$ \\
\hline E. kebericho & 1000 & $50.18 \pm 1.90$ & $49.53 \pm 1.90$ & $10.31 \pm 0.67$ \\
& 500 & $65.28 \pm 0.764$ & $34.66 \pm 0.76$ & $9.91 \pm 0.63$ \\
& 250 & $77.780 \pm 0.87$ & $22.13 \pm 0.87$ & $6.78 \pm 0.20$ \\
$Z$. officinale & 1000 & $67.06 \pm 1.03$ & $32.83 \pm 1.03$ & $7.33 \pm 0.51$ \\
& 500 & $76.31 \pm 1.49$ & $23.49 \pm 1.47$ & $6.38 \pm 0.24$ \\
& 250 & $80.03 \pm 0.84$ & $19.87 \pm 0.84$ & $6.28 \pm 0.20$ \\
Negative control & & $5.14 \pm 0.37$ & $94.79 \pm 0.37417$ & $13.00 \pm 0.00$ \\
\hline
\end{tabular}

Key: Values are expressed as Mean \pm SEM, n=5: TWN80=Tween 80

Extracts of both plants failed to protect weight loss of mice infected with rodent malaria at all doses levels $(p>0.05))$ and no significant difference was observed between the experimental arm and the untreated groups (Table 3).

Table 3: Effects of $70 \%$ methanol extracts of both plant materials on body weights of $P$. berghei infected mice in the antiplasmodial activity studies

\begin{tabular}{lllll}
\hline & \multicolumn{4}{l}{ Body weight (gm) } \\
\hline Extracts & $\begin{array}{l}\text { Doses } \\
(\mathrm{mg} / \mathrm{kg})\end{array}$ & D 0 & D 14 & P- value \\
\hline E. kebericho & 1000 & $33.20 \pm 2.200$ & $31.60 \pm 1.60$ & 0.001 \\
& 500 & $31.20 \pm 0.97$ & $28.40 \pm 1.50$ & 0.009 \\
Z. officinale & 250 & $31.20 \pm 2.50$ & $28.60 \pm 2.70$ & 0.007 \\
& 1000 & $32.20 \pm 0.970$ & $26.50 \pm 1.17$ & 0.00 \\
\multicolumn{1}{|l}{$25 \mathrm{mg} / \mathrm{kg} \mathrm{CQ}$} & 500 & $30.00 \pm 1.00$ & $26.00 \pm 0.81$ & 0.00 \\
\multirow{2}{*}{ Negative control } & 250 & $27.40 \pm 2.31$ & $24.60 \pm 2.23$ & 0.002 \\
& $24.40 \pm 1.88$ & $24.40 \pm 1.88$ & $22.80 \pm 1.65$ & 0.016 \\
\hline
\end{tabular}

Key: Values are significant at 95\% CI and $\mathrm{p}$-value $<0.05$ : TWN80=Tween $80, \mathrm{n}=5$

Assessment of the mean survival times of mice in all test groups was compared to the negative control groups (Table 4). It was also observed that mice treated with all doses of extracts lived longer than the negative control in a dose dependent manner. The study showed that $70 \%$ methanol crude extracts were able to protect reduction in $\mathrm{PCV}$ in a dose depended manner when compared to the control groups (Table 5). 
Table 5: The effects of $70 \%$ methanol rhizome extracts of E. kebericho Mesfin and Z. officinale Roscoe on PCV of $P$. berghei infected treated mice

\begin{tabular}{lll}
\hline \multirow{2}{*}{ Extract doses } & \multicolumn{2}{c}{ PCV (\%) on day 4} \\
\cline { 2 - 3 } & \multicolumn{1}{c}{ Plant extract } \\
\cline { 2 - 3 } & E. kebericho Mesfin & Z. officinale Roscoe \\
\hline $5000 \mathrm{mg} / \mathrm{kg}$ & $45.96 \pm 1.08$ & $33.46 \pm 1.08$ \\
$250 \mathrm{mg} / \mathrm{kg}$ & $39.70 \pm 0.44$ & $20.04 \pm 0.32$ \\
$25 \mathrm{mg} / \mathrm{kg} \mathrm{CQ}$ & $33.00 \pm 0.81$ & $22.10 \pm 1.18$ \\
Negative control & $49.62 \pm 0.34$ & $49.62 \pm 0.34$ \\
\hline
\end{tabular}

\section{DISCUSSION}

Using plants as traditional remedies started from the antiquity to the present day for every day health care needs of human being including malaria (36). Accordingly, about $90 \%$ of Ethiopians, and $80 \%$ of the world population rely primarily on plant products for their healthcare for more than a century (10). Societies always believe that plant product is safe, non-toxic or have negligible health hazards. Accordingly, E. Kebericho Mesfin and Z. officinale Roscoe are among traditionally used medicinal plants against wide ranges of diseases including malaria in Ethiopia (37). P. berghei causes acute malaria in rodents and sensitive to CQ and non-infectious to human. It is is widely used elsewhere in the world for in vivo evaluation of antimalarial agents. The oral acute toxicity evaluation of $\mathrm{nE}$. Kebericho Mesfin was conducted prior to antiplasmodial studies to rule out the LD50. Hence, the current finding showed that $70 \%$ methanolic rhizome extract of the plant was non-toxic at $5 \mathrm{~g} / \mathrm{kg}$ of body weight in all study parameters.

The antiplasmodial activities of both plant materials in a four day suppressive test showed remarkable chemo - suppression of $49.53 \pm 1.90 \%$ and $32.83 \pm 1.03$ respectively .The finding further reflected that the corresponding longer mean survival times compared to all other doses and the negative controls in a dose dependent manner. This suggests that $1000 \mathrm{mg} / \mathrm{kg}$ of an extract of $E$. Kebericho Mesfin might be the desirable therapeutic dose in the experimental animals. Increasing the dose of $Z$. officinale Roscoe beyond
$1000 \mathrm{mg} / \mathrm{kg}$ body weight could result in best chemo - suppressive effect than the currently explained findings.

The antiplasmodial activities of these plants suggest that inhibitory effects on parasite replication. These could be due to the presence of active compounds in the test extracts $(38-40)$ that are evenly distributed among plant species of the family. Studies elsewhere revealed that high degree of parasitemia suppression might be explained by mechanisms of biomarker actions having an indirect effect on the immune system or by other pathways that are not yet fully understood (41) in mice.

Previously isolated chemical compounds from Echinops species include alkaloids, saponins, phytosterols, polyphenols, carotenoids, Sesquiterpenes (alcohols/ lactones), lignans, acetylenic \& thiophene compounds and essential oil. Specially, Sesquiterpenes was claimed to be antimalarial agents (42) which strongly supports the current finding. In vitro studies from the family Asteraceae like Dicoma tomentosa (43), Microglossa pyrifolia (44), Oncosiphon piluliferum, Artemisia gorgonum Webb, Anthemis auriculata Boiss (45) reported to show antiplasmodial activities against $P$. falciparum. Thus, this evidence coupled with the traditional claims suggested the antiplasmodial biomarkers are evenly distributed among the species of the same family. The antiplasmodial effect of $Z$. officinale Roscoe is also in support with previous in vitro studies such as Aframomum zambesiacum K. Schum and Kaempferia marginata Carey 
reported to have antiplasmodial activities from the family Zingiberaceae (45).

The current findings are strongly supported by two evidences. First, the traditional claims of both plants as antimalarial remedies. Secondly, the presence of Sesquiterpenes as an antiplasmodial agent in the crude extract of E. kebericho Mesfin and in viro studies of both plant species of the same families.

In conclusion, at the maximum experimental dose level of $5 \mathrm{~g} / \mathrm{kg}$, E. Kebericho Mesfin showed no acute toxicity; and therefore, the LD50 of the plant was found to be beyond the concentration we used. The $70 \%$ methanolic extracts of both plants showed a dose dependent suppression of parasitemia. Hence, this study indicated that both plants have promising antiplasmodial activities against $P$. berghei whichsupports their traditional uses. Finally, the authors recommend that further in vitro studies on $P$. falciparum should be conducted to validate the antiplasmodial activities of both plants for routine health care use.

\section{ACKNOWLEDGEMENTS}

The authors would like to acknowledge Jimma University for the financial assistance. We would also like to thank the Ethiopian Public Health Institute for a donation of experimental animals, provision of standard parasites and pertinent training for the principal investigator. We would also like forward our gratitude to Professor Bart De Spiegeleer and Dr. Game Urge for commenting and editing the whole manuscript.

\section{REFERENCES}

1. WHO. World malaria report 2016: World Health Organization; 2016.

2. Grueninger $\mathrm{H}$, Hamed $\mathrm{K}$. Transitioning from malaria control to elimination: the vital role of ACTs. Trends in Parasitology. 2013;29(2):604.

3. Cheeseman $\mathrm{IH}$ MB, Nair S, Nkhoma $S$, Tan A, Tan JC, Al Saai S, Phyo AP, Moo CL, Lwin KM. A major genome region underlying artemisinin resistance in malaria.Science.2012; 336(6077):79-82.

4. Dondorp AM YS, White L, Nguon C, Day NP, Socheat D, von Seidlein L. Artemisinin resistance: current status and scenarios for containment. Nature Reviews Microbiology. 2009;8(4):272-80.

5. Phyo AP NS, Stepniewska K, Ashley EA, Nair S, McGready R, ler Moo C, Al-Saai S, Dondorp AM, Lwin KM. Emergence of artemisinin-resistant malaria on the western border of Thailand: a longitudinal study. The Lancet 2012;415(6872):686-93.

6. Ridley RG. Medical need, scientific opportunity and the drive for antimalarial drugs. Nature. 2002;415(6872):686-93.

7. Zirihi GN, Mambu L, Guede-Guina F, Bodo $\mathrm{B}$, Grellier P. In vitro antiplasmodial activity and cytotoxicity of 33 West African plants used for treatment of malaria. Journal of ethnopharmacology. 2005;98(3):281-5.

8. Gedif T, Hahn H-Jr. The use of medicinal plants in self-care in rural central Ethiopia. Journal of Ethnopharmacology. 2003;87(2):155-61.

9. Schuster BG. Demonstrating the validity of natural products as anti-infective drugs. The Journal of Alternative \& Complementary Medicine. 2001;7(1):73-82.

10. Cameron A, Ewen M, Auton M, Abegunde D. The world medicines situation 2011. Medicine prices, availability and affordability[http://www who int/medicines/areas/policy/world_medicines_s ituation/WMS_ch6_wPricing_v6 pdf]. 2011.

11. Mesfin A, Giday $M$, Animut A, Teklehaymanot T. Ethnobotanical study of antimalarial plants in Shinile District, Somali Region, Ethiopia, and in vivo evaluation of selected ones against Plasmodium berghei. Journal of Ethnopharmacology. 2012;139(1):221-7.

12. Tsim KWK. Youyou Tu: The Nobel Prize in Physiology or Medicine 2015. Department of Life Science, HKUST Science School, Hong Kong. 2015. 
13. Waako P KE, Smith P, Folb P. . East African medicinal plants as a source of lead compounds for development of new antimalarial drugs. Afr J Ecol. 2007;45(1-5).

14. Giday M, Asfaw Z, Elmqvist T, Woldu Z. An ethnobotanical study of medicinal plants used by the Zay people in Ethiopia. Journal of Ethnopharmacology. 2003;85(1):43-52.

15. Abera B NL, Kumlehn J. In vitro and ex vitro seed-based propagation methods of Echinops kebericho Mesfin: A threatened medicinal plant.The Society For Advancement of Horticulture. 2008;10(2):164-8.

16. Kemper KJ. Ginger (Zingiber officinale). Longwood Herbal Task Force, Availabe at: http://www mcp edu/herbal/default htm. 1999:1-18.

17. Abebe D DA, Urga K. Illustrated Checklist, Medicinal Plants and Other Useful Plants of Ethiopia: Ethiopian Health and Nutrition Research Institute; 2003.

18. Vincent P.K. Titanji DZaMNN. The Antimalarial Potential of Medicinal Plants used for the treatment of malaria in Cameroonian Folk Medicine. African Journal of Traditional, Complementary And Alternative Medicines. 2008;5(3):302 - 21

19. Idowu O SO, Ajana O, Aworinde D. Ethnobotanical survey of antimalarial plants used in Ogun State, Southwest Nigeria. African Journal of Pharmacy and Pharmacology 2010;4(2):055-60.

20. http://www.maplandia.com/ethiopia/oromiya/ west-shewa/gonfi-k-edida/gonfi-k-edidagoogle-earth.html. Accessed on 15/11/2017 aP.

21. Innocent $\mathrm{E}$, Moshi M, Masimba $\mathrm{P}, \mathrm{Mbwambo}$ Z, Kapingu M, Kamuhabwa A. Screening of traditionally used plants for in vivo antimalarial activity in mice. African Journal of Traditional, Complementary and Alternative Medicines. 2009;6(2).

22. Peter A. The current global malaria situation. Malaria parasite biology,pathogenesis, and protection. ASM Press WDC. 1998;1:1-22.

23. Fidock DA RP, Croft SL, Brun R, Nwaka S. Antimalarial drug discovery: efficacy models for compound screening. Supplementary
documents.Trends Parasitology. 2004;15:1929.

24. Lorke D. A new approach to practical acute toxicity testing. Archives of toxicology. 1983;54(4):275-87.

25. Dikasso D, Makonnen E, Debella A, Abebe D, Urga K, Makonnen W, et al. In vivo antimalarial activity of hydroalcoholic extracts from Asparagus africanus Lam. in mice infected with Plasmodium berghei. Ethiopian Journal of Health Development. 2007;20(2):112-8.

26. Salawu O CB, Tijani A, Obidike I, Salawu T, Akingbasote AJ. Acute and sub-acute toxicological evaluation of the methanolic stem bark extract of Crossopteryx febrifuga in rats. African Journal of Pharmacy and Pharmacology. 2009;3:621-6.

27. Rehman R, Akram M, Akhtar N, Jabeen Q, Shah SA, Ahmed K, et al. Zingiber officinale Roscoe (pharmacological activity). Journal of Medicinal Plants Research. 2011;5(3).

28. Dong AMBaZ. The Amazing and Mighty Ginger - Herbal Medicine - NCBI Bookshelf. https://www.ncbi.nlm.nih.gov/books/NBK927 75/. Accessed on 14/11/2017 at 5:30 PM. 2011.

29. Peters W. Antimalarial drug resistance: an increasing problem. British Medical Bulletin. 1982;38(2):187-92.

30. Fidock DA, Rosenthal PJ, Croft SL, Brun R, Nwaka S. Antimalarial drug discovery: efficacy models for compound screening. Nature Reviews Drug Discovery. 2004;3(6):509-20.

31. David AF P, J. R., Simon, L.C., Reto B., and, N. S. Antimalarial drug discovery: Efficacy models for compound screening. Nature Reviews. 2004;3:509-20.

32. Carvalho LH, Brandao MGL, Santos-Filho D, Lopes JLC aKA. Antimalarial activity of crude extracts from Brazilian plants. Studied in vivo in Plasmodium berghei-infected mice and in vitro against Plasmodium falciparum inculture. Braz J MedBiol Res. 1991;24:111323.

33. WHO. The biology of malaria parasites: report of a WHO scientific group [meeting held in

DOI: http://dx.doi.org/10.4314/ejhs.v28i5.17 
Washington, DC, from 24 to 28 September 1984]. 1987.

34. Elufioye TO, Agbedahunsi JM. Antimalarial activities of Tithonia diversifolia (Asteraceae) and Crossopteryx febrifuga (Rubiaceae) on mice in vivo. Journal of Ethnopharmacology. 2004;93(2â€“"3):167-71.

35. Gurib-Fakim A. Medicinal plants: Traditions of yesterday and drugs of tomorrow. Molecular Aspects of Medicine. 2006;27(1):193.

36. Lu Y, Hernandez P, Abegunde D, Edejer T. The world medicines situation 2011. Medicine expenditures World Health Organization, Geneva. 2011.

37. Hymete A RJ, Iversen TH, Kjøsen H. Volatile constituents of the roots of Echinops kebericho Mesfin. Flavour and fragrance journal. 2007;22(1):35-8.

38. Koch A TZ, Pezzato J, and, Soejarto D. Evaluation of plants used for a ntimalarial treatment by the Masai people of Kenya. Journal of Ethnopharmacology. 2005;101:959.

39. Tariku Y HA, Hailu A, Rohloff J. In vitro evaluation of antileishmanial activity and toxicity of essential oils of Artemisia absinthium and Echinops kebericho. Chemistry \& biodiversity. 211;8(4):614-23.

40. Muthaura C, Rukunga G, Chhabra S, Mungai G, Njagi E. Traditional antimalarial phytotherapy remedies used by the Kwale community of the Kenyan Coast. Journal of ethnopharmacology. 2007;114(3):377-86.

41. Hymete A, Iversen TH, Rohloff J, Erko B. Screening of Echinops ellenbeckii and Echinops longisetus for biological activities and chemical constituents. Phytomedicine. 2005;12(9):675-9.

42. Jansen O, Tits M, Angenot L, Nicolas J-P, De Mol P, Nikiema J-B, et al. Anti-plasmodial activity of Dicoma tomentosa (Asteraceae) and identification of urospermal A-15-Oacetate as the main active compound. Malar $J$. 2012;11:289.

43. Ayuko TA, Njau RN, Cornelius W, Leah N, Ndiege IO. In vitro antiplasmodial activity and toxicity assessment of plant extracts used in traditional malaria therapy in the Lake Victoria Region. Mem $\tilde{A}^{3}$ rias do Instituto Oswaldo Cruz. 2009;104(5):689-94.

44. Bero J, Fredrich M, Quetinâ€ Leclercq Jl. Antimalarial compounds isolated from plants used in traditional medicine. Journal of Pharmacy and Pharmacology. 2009;61(11):1401-33. 